\title{
Use and overuse of proton pump inhibitors
}

\author{
Annamaria Staiano ${ }^{*}$, Paolo Quitadamo \\ From 71st Congress of the Italian Society of Pediatrics. Joint National Meeting SIP, SIMGePeD, Study Group \\ on Pediatric Ultrasound, SUP Study Group on Hypertension \\ Rome, Italy. 4-6 June 2015
}

In 2009, an editorial by Putman focused on the dramatic increase in the use of proton pump inhibitors (PPIs) in infants [1]. Considering the increasing evidence that PPIs offer little benefit for most of the symptoms for which they are prescribed, Putman strongly highlighted the need for a serious effort to curtail their empiric use. The editorial was linked to a study by Orenstein et al, which detected no difference in efficacy between lansoprazole and placebo for symptoms attributed to gastroesophageal reflux disease (GERD) in infants [2]. A very recent review on the effects of PPIs on irritability and crying in infants confirmed the conclusion that these drugs do not offer relief from these symptoms for which they are commonly prescribed [3]. After all, it has recently been pointed out that volume rather than acid is often the key promoter of reflux-associated symptoms in infants. Distension-induced increase in gastric wall tension has been associated with high rates of transient lower esophageal sphincter relaxations and is considered one of the main mechanisms contributing to postprandial GER [4]. Despite all these evidences on PPIs uneffectiveness for many of the symptoms for which they are commonly prescribed, the rate of their prescriptions have exponentially increased over the last years. The latest combined NASPGHAN/ESPGHAN guidelines already in 2009 highlighted the need to distinguish physiologic GER events from GERD, limiting for the latter the use of PPIs [5]. However, a 2012 European survey carried out by our study group showed that only $1.8 \%$ of pediatricians reported a complete adherence to the guideline recommendations in their clinical practice. The most relevant violation of the guideline recommendations concerned the prescription of unnecessary acid suppressive medications [6] (Figure 1). In order to inquire into the reasons why pediatricians did not follow

\footnotetext{
* Correspondence: staiano@unina.it

Department of Translational Medical Science, Section of Pediatrics, University of Naples "Federico II", Naples, Italy
}

(c) 2015 Staiano and Quitadamo. This is an Open Access article distributed under the terms of the Creative Commons Attribution License (http://creativecommons.org/licenses/by/4.0), which permits unrestricted use, distribution, and reproduction in any medium, provided the original work is properly cited. The Creative Commons Public Domain Dedication waiver (http://creativecommons.org/ publicdomain/zero/1.0/) applies to the data made available in this article, unless otherwise stated. the guideline recommendations, we performed another trial with the same pediatricians undergoing specific training on the guidelines being supervised in their clinical practice. As a result, trained pediatricians showed a significantly higher compliance with the international guidelines and infants with unexplained crying and distressed behaviour or with uncomplicated recurrent regurgitation and vomiting who were unproperly prescribed PPIs decreased dramatically [7]. Besides these data on PPI overuse, recent studies highlighted the occurrence of several adverse effects related to their assumption, such as a higher risk of bronchoalveolar lavage culture positivity and gastric bacterial overgrowth, food allergy, Clostridium difficile infection, gastric polyps and nodules [8-12].

Published: 30 September 2015

\section{References}

1. Putnam PE: Stop the PPI Express: They Don't Keep Babies Quiet! J Pediatr 2009, 154(4):475-476.

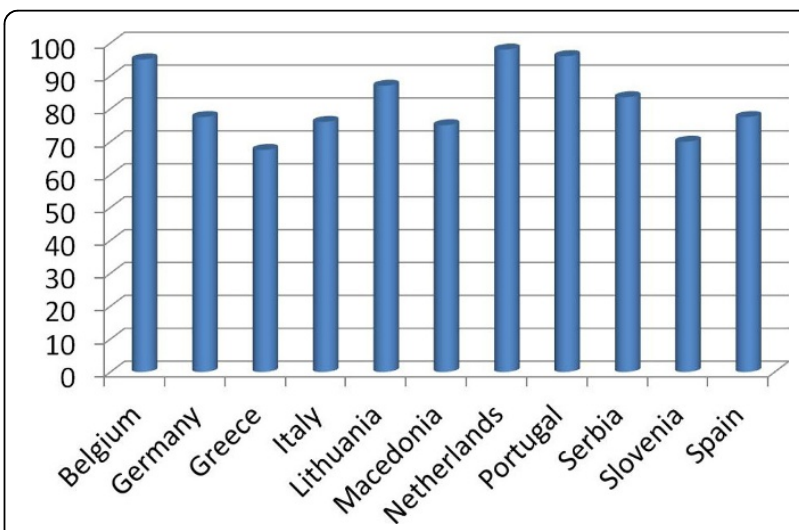

Figure 1 Rates of pediatricians over-prescribing PPIs in the different European countries 
2. Orenstein $S R$, Hassall E, Furmaga-Jablonska W, Atkinson S, Raanan M: Multicenter, double-blind, randomized, placebo-controlled trial assessing efficacy \& safety of proton pump inhibitor lansoprazole in infants with symptoms of gastroesophageal reflux disease. J Pediatr 2009, 154(4):514-520.e4.

3. Gieruszczak-Białek D, Konarska Z, Skórka A, Vandenplas Y, Szajewska H: No effect of proton pump inhibitors on crying and irritability in infants: systematic review of randomized controlled trials. J Pediatr 2015, 166(3):767-70.

4. Orenstein SR: Infant GERD: symptoms, reflux episodes \& reflux disease, acid \& non-acid refllux-implications for treatment with PPIs. Curr Gastroenterol Rep 2013, 15(11):353.

5. Vandenplas Y, Rudolph CD, Di Lorenzo C, Hassall E, Liptak G, Mazur L, et al: Pediatric gastroesophageal reflux clinical practice guidelines: joint recommendations of the North American Society for Pediatric Gastroenterology, Hepatology, and Nutrition (NASPGHAN) and the European Society for Pediatric Gastroenterology, Hepatology, and Nutrition (ESPGHAN). J Pediatr Gastroenterol Nutr 2009, 49(4):498-554.

6. Quitadamo P, Papadopoulou A, Wenzl T, Urbonas V, Kneepkens F, Roman E, et al: European Pediatricians' Approach to Children with Gastroesophageal Reflux Symptoms: Survey on the Implementation of 2009 NASPGHAN-ESPGHAN Guidelines. J Pediatr Gastroenterol Nutr 2014, 58(4):505-509.

7. Quitadamo P, Urbonas V, Papadopoulou A, Roman E, Pavkov DJ, Orel R, et al: Do pediatricians apply the 2009 NASPGHAN-ESPGHAN guidelines for the diagnosis and management of gastroesophageal reflux after being trained? J Pediatr Gastroenterol Nutr 2014, 59(3):356-359.

8. Rosen R, Johnston N, Hart K, Khatwa U, Katz E, Nurko S: Higher rate of bronchoalveolar lavage culture positivity in children with nonacid reflux and respiratory disorders. J Pediatr 2011, 159(3):504-506.

9. Rosen R, Amirault J, Liu H, Mitchell P, Hu L, Khatwa U, et al: Changes in gastric and lung microflora with acid suppression: acid suppression and bacterial growth. JAMA Pediatr 2014, 168(10):932-937.

10. Trikha A, Baillargeon JG, Kuo YF, Tan A, Pierson K, Sharma G, et al: Development of food allergies in patients with gastroesophageal reflux disease treated with gastric acid suppressive medications. Pediatr Allergy Immunol 2013, 24(6):582-588.

11. Turco R, Martinelli M, Miele E, Roscetto E, Del Pezzo M, Greco L, et al: Proton pump inhibitors as a risk factor for paediatric Clostridium difficile infection. Aliment Pharmacol Ther 2010, 31(7):754-759.

12. Pashankar DS, Israel DM: Gastric polyps and nodules in children receiving long-term omeprazole therapy. J Pediatr Gastroenterol Nutr 2002, 35(5):658-662.

doi:10.1186/1824-7288-41-S2-A68

Cite this article as: Staiano and Quitadamo: Use and overuse of proton pump inhibitors. Italian Journal of Pediatrics 2015 41(Suppl 2):A68.

\section{Submit your next manuscript to BioMed Central and take full advantage of:}

- Convenient online submission

- Thorough peer review

- No space constraints or color figure charges

- Immediate publication on acceptance

- Inclusion in PubMed, CAS, Scopus and Google Scholar

- Research which is freely available for redistribution 